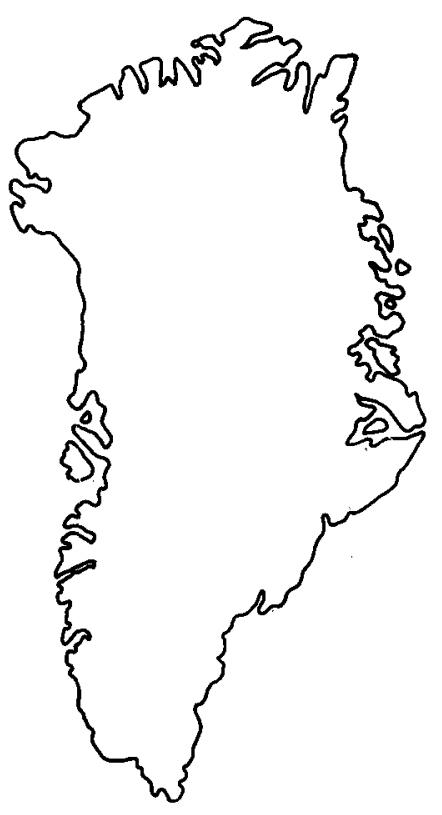

\title{
New methods for the geological analysis of Tertiary volcanic formations on Nuussuaq and Disko, central West Greenland, using multi-model photogrammetry
}

\author{
Asger Ken Pedersen \& Keld S. Dueholm
}

\begin{abstract}
A series of experiments with multi-model photogrammetry were made during the compilation of a $80 \mathrm{~km}$ long section along the south coast of Nuussuaq. The section covers a range of Tertiary volcanic lithologies which overlie Mesozoic to Tertiary clastic sediments.

The multi-model method allows the geological analyses of flat-lying lithologies in steep or inaccessible terrain and the compilation of detailed sections, profiles, and block diagrams.

Drawing of sections or maps is combined with accurate structural measurements to document the flow directions of both subaerial and subaqueous volcanic units and to demonstrate syn-and post-volcanic basin movements and the location of volcanic eruption sites.

Multi-model photogrammetry experiments made by compiling the geology of areas already covered by field work has led to major new discoveries. Similar experiments made on areas, which had not been visited in the field before the compilation, but which were visited later, demonstrates that the method is an important new tool in geological reconnaissance.
\end{abstract}

\section{A. K. P., Geological Museum, Øster Voldgade 5-7, DK-1350 Copenhagen K, Den-} mark.

K. S. D., Institute of Surveying and Photogrammetry, Technical University of Denmark, DK-2800 Lyngby, Denmark.

The Vaigat strait which separates Nuussuaq and Disko in central West Greenland is a U-shaped glaciercarved channel about $80 \mathrm{~km}$ long (Fig. 1). Feared for its fierce gales and admired for its striking beauty, the Vaigat provides a magnificent geological section through the volcanic rifted margin of West Greenland. The steep south coast of Nuussuaq facing the Vaigat provides continuous exposures of Tertiary volcanic formations. Already in 1900 Steenstrup had published a large coloured section of the coastal wall made by the artist $\mathrm{H}$. Moltke who took part in an expedition to Greenland primarily for this specific purpose. The western part of the section is covered by a geological map sheet (1:100 000 Qutdligssat 70 V.1 S). In the eastern part of the section some information about the volcanic rocks and their interaction with sediments was compiled by Koch (1959) and Koch \& Pedersen (1960). The volcanic formations on the south coast of Nuussuaq are mainly exposed on steep-walled to almost vertical mountain sides and large parts of the exposures are inaccessible. The volcanic rocks can therefore neither be mapped in detail by conventional mapping nor from vertical aerial photographs. Because of its geological importance for the study of the West Greenland Cretaceous to Tertiary Basin, the section along the Vaigat coast has therefore remained a geological challenge for decades.

With the introduction of the analytical plotter, quantitative analysis of black and white oblique areal photographs became possible, and as an experiment a few pairs of old oblique aerial photographs from the Vaigat coast were analysed by Dueholm \& Pedersen (1988) using a Kern DSR11 instrument. While the analysis with the analytical plotter was a great improvement, the geological resolution of the old and fairly coarsegrained films was not entirely satisfactory.

The development of the multi-model photogrammetry system has opened up for large scale detailed geological analysis of the volcanic sequence in central West Greenland. The Nuussuaq section along the Vaigat is 


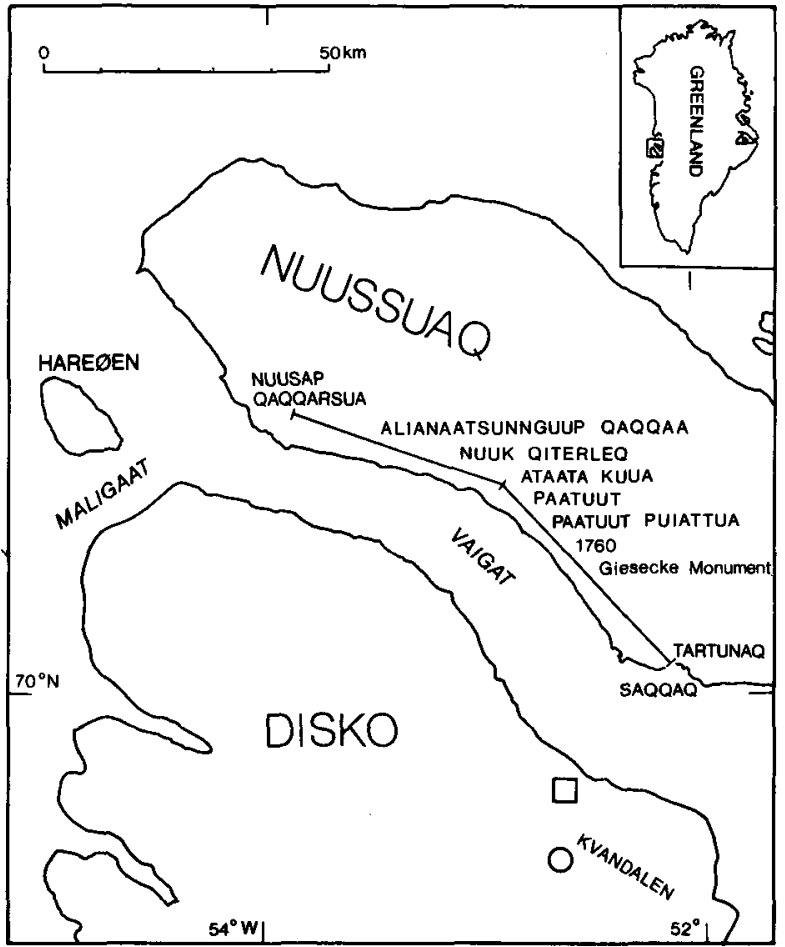

Fig. 1. Map showing Nuussuaq and parts of Disko. The kinked line indicates the large profile compiled photogrammetrically along the south coast of Nuussuaq from Tartunaq in the east to Nuusap Qaqqarsua in the west. The square on Disko indicates the innermost part of Kvandalen with the position of the block diagram shown in Fig. 6. The open circle indicates the position of section 2 shown in Fig. 5.

the object of the first large scale photogrammetrical experiment with the method. Preliminary results of this work were presented by Dueholm \& Pedersen (1990).

In this paper we present a range of examples from the ongoing photogrammetric analysis of the volcanic geology on Nuussuaq and Disko, chosen to illustrate various capabilities of the multi-model method. Most of the examples derive from the section along the south coast of Nuussuaq from Nuusap Qaqqarsua in the west to Tartunaq in the east (Fig. 1). In addition detailed work is presented from north-east Disko. First the working procedures are outlined, exemplified by the Vaigat coast section. Then a series of photogrammetrical sections at different scales are presented, supplemented by a block diagram. The following examples show detailed compilations of second order features like dips and strikes, and thickness variations. Finally we present a section compiled from an area where no geological field observations existed at the time of compilation.

\section{Photography}

The Nuussuaq coastal section is about $80 \mathrm{~km}$ long (Fig. 1). In the western part of the section a steep and well-exposed mountain side rises above a talus slope at a distance of 1 to $2.5 \mathrm{~km}$ from the coast. To the east this distance increases to 3 to $6 \mathrm{~km}$. The heights of the mountain tops capping the coastal wall rise from about $1250 \mathrm{~m}$ in the west to about $2000 \mathrm{~m}$ in the central part of the section and then decline to below $1200 \mathrm{~m}$ in the easternmost part.

The small-frame colour photographs used for multimodel work in this study were taken out of the open window of a Bell 206 helicopter flying at cruising speeds between 60 and $120 \mathrm{~km}$ per hour. A Hasselblad SWC Camera with a $40 \mathrm{~mm}$ lens and a 70-exposure cassette was used for the photography. In order to obtain a sufficiently detailed resolution of the volcanic features in the section the photographs were taken at distances between 500 and $1500 \mathrm{~m}$ from the mountain sides, and from heights typically varying between 800 and $1600 \mathrm{~m}$. The colour photographs applied in this study therefore do not cover the lowermost (non-volcanic) parts of the section from sea level and several hundred metres upwards. To fill out these gaps existing old oblique or vertical aerial photographs were utilised. In several cases, the same objects were photographed at different scales varying between 1:10 000 and 1:40 000. An example of one of the photographs used in multi-model photogrammetry is shown in Fig. 2.

The photographs were taken with 60 to $80 \%$ overlap, and the stereoscopic models were usable for multimodel photogrammetry, except when the helicopter had turned too sharply, causing the direction of the camera axes between two consecutive photographs to deviate by more than $20^{\circ}$ (Dueholm, 1992). The exposure time of $1 / 250 \mathrm{sec}$. was found to give sufficiently sharp images for the present work. However faster exposure is recommended whenever possible in order to reduce blur from image motion. Some photographs were underexposed, but even these could be used thanks to the strong image illumination in the Kern DSR15 instrument used for the project.

\section{Model orientation}

For the geological compilation of the Vaigat section, 8 sets of templates (Dueholm, 1992) with $60 \times 60 \mathrm{~mm}$ colour photographs were mounted to cover the westernmost $60 \mathrm{~km}$ of the section from Nuusap Qaqqarsua to just east of Giesecke Monument. One set of templates containing 3 different multi-model blocks were mounted to partly cover the easternmost $20 \mathrm{~km}$ towards 
Tartunaq. Gaps between and below the blocks were covered by vertical aerial photographs. In total, the Vaigat coast section is covered by 9 sets of templates with 125 colour stereo models supplemented by 6 vertical and 5 oblique aerial photograph models.

\section{Control points}

Earlier photogrammetrical work in the Nuussuaq and Disko area (Dueholm \& Pedersen, 1988) has shown that a consistent control point system cannot be obtained by measuring from the published topographical maps of the area $(1: 250000 / 50 \mathrm{~m}$ contour intervals). The application of such points for multi-model work will invariably result in a major loss of precision and accuracy.

The photogrammetrical laboratory at GGU has recently carried out an aerotriangulation based on 1:150 000 super wide angle vertical aerial photographs covering the Disko and Nuussuaq areas as a basis for the production of a new set of 1:100 000 topographical maps. Points measured in these aerotriangulated photographs form the basis of all our work. However, because of the large difference in scale between the colour stereo photographs $(1: 10000$ to $1: 40000)$ and the aerial photographs it is very difficult to obtain a sufficiently densely spaced set of control points by direct measurements on the aerial photographs, particularly on the slopes and steep walls of the Vaigat coastal section. For this reason only, a set of widely spaced points were obtained from the 1:150 000 aerial photographs. These points were then used to orientate a series of $c .1: 45000$ old vertical acrial photographs which also cover the areas of interest for the multi-model work. A second and much more densely spaced set of points could then be measured on the 1:45000 photographs. These points were used for the orientation of both oblique aerial photographs and for the small-frame colour photographs.

The most severe photogrammetrical problems were encountered in a few situations where the old oblique and vertical aerial photographs were partly defect. In these cases the small-frame colour photographs were orientated from points transferred directly from the 1:150 000 photographs.

\section{Accuracy}

A larger number of control points than necessary were measured in this first large scale multi-model experiment, which made it possible to evaluate the quality of the orientations and the precision in point transfer. Approximately 300 points were read from the 1:45000 aerial photographs and also measured on the colour photographs. Enlarged black and white paper copies of all colour photographs were made to mark the position of the control points.

After the point system just described was established
Fig. 2. A typical photograph used in multi-model photogrammetry. The photograph was taken with a Hasselblad SWC camera with a $40 \mathrm{~mm}$ lens and shows a motive with Tertiary volcanic rocks at Paatuut. Arrows point to the position of the boundary between the Vaigat Formation (below) and the Maligât Formation (above). At this locality the Vaigat Formation consists of picritic hyaloclastite $(\mathrm{H})$, picritic lavas $(\mathrm{P})$, and plagioclase porphyritic basalt (B). The Maligât Formation consists of evolved basaltic lavas (B). One of these (marked $\mathrm{Th}$ ) has been measured in detail (Figs 13 and 14).

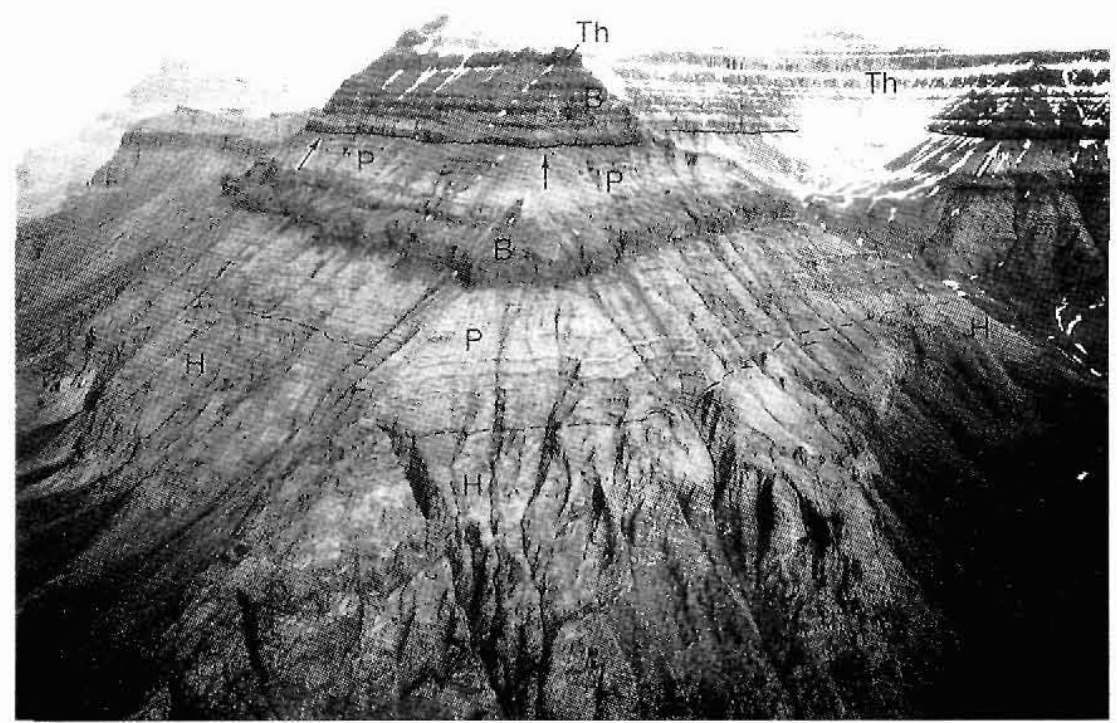




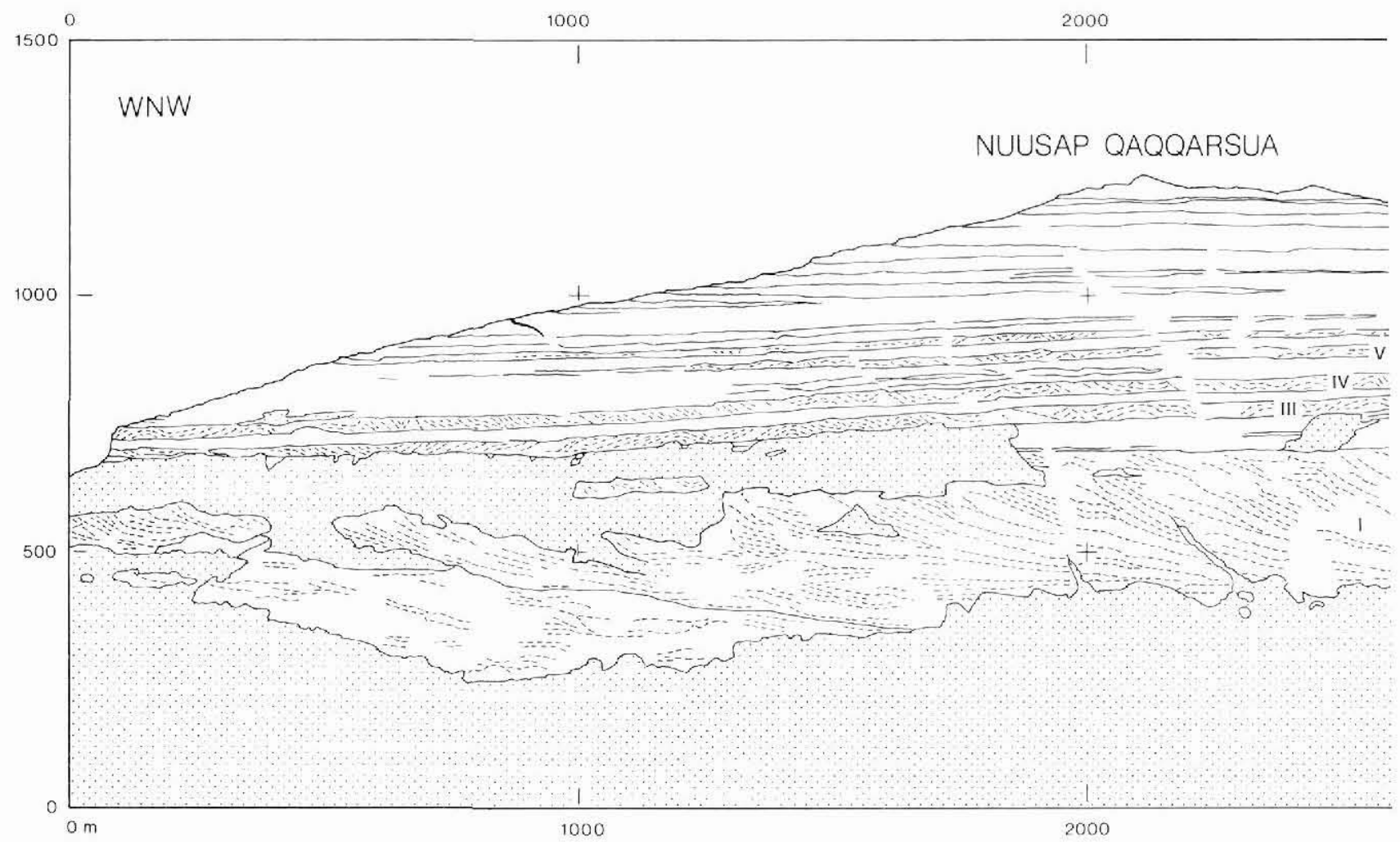

and stored in data files, the multi-model templates were orientated as outlined by Dueholm (1992). The standard deviation of point transfer was $3 \mathrm{~m}$ in plane and 2 $\mathrm{m}$ in height. This includes the accumulated error of control point transfer from the 1:150 000 aerotriangulated photographs via the 1:45000 aerial photographs to the colour photographs. Less than $5 \%$ of the points were abandoned due to gross errors from misidentification. An additional inaccuracy was added from the underlying 1:150 000 aerotriangulation resulting in an absolute standard deviation of about $5 \mathrm{~m}$ in plane and about $3 \mathrm{~m}$ in height. Experiments using reduced control point sets in some multi-model blocks showed that the same accuracy could have been obtained by using less than half of the number of measured control points, that is, about one point per model.

The inner consistency (precision) within one multimodel block was much better than the accuracies just described. The precision depends on the photograph scale and is better than $0.5 \mathrm{~m}$ in height on a photograph scale of about 1:20000.

In general, the accuracy and precision obtained have been better than the requirements for an accurate geological analysis of a volcanic province.

\section{Time use in orientation of models}

The time used in the orientation of a multi-model block depends on the number of models involved and the measurement of control points. In the present project the average time spent was about one hour per model, the time equally distributed between the mounting of photographs on templates, the photogrammetric measurement of tic-points between photographs, and the two-step measurement of control points in the aerial photographs. The resetting of a previously orientated multi-model block requires only 10 minutes.

While the initial orientation procedure was time-consuming, the finally orientated multi-model blocks were removed from the instrument many times and re-installed, because re-installation requires only 10 minutes. The time spent with the geological photogrammetric analyses very much exceeded the time spend on orientation. Furthermore, after the compilation of the geological section along the Vaigat, the stored multi-model blocks can be used in later geological projects. 


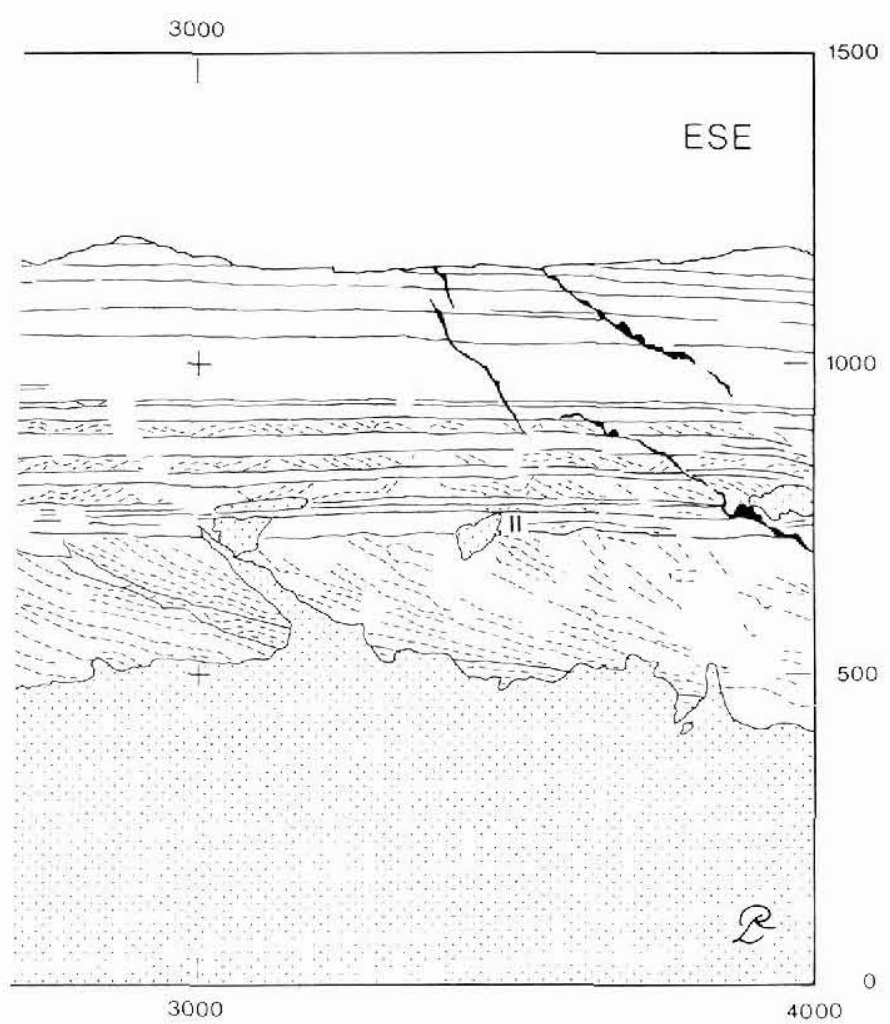

\section{Geological photogrammetry}

\section{Geological setting}

The geological section along the south coast of Nuussuaq exposes early Tertiary volcanic rocks overlying Cretaceous clastic sediments. The volcanic rocks both cover and are interlayered with clastic Tertiary sediments. The volcanic rocks comprise subaerial lava flows, some of which are very small and form sequences of thin lavas, while other lavas are very large and form extensive plateau basalt sheets. The volcanic rocks also comprise subaqueous pillow lavas and hyaloclastites, formed when magma entered water. Most hyaloclastites were formed when subaerial lava flows entered water filled basins, but others were formed when magma erupted directly into a water covered basin. Some basins were marine, others freshwater lakes, some were brackish from time to time. Considerable basin movements occurred prior to, during and after the volcanism, and these movements affected different parts of the basin at different times.

Conventional mapping and photogrammetry based on vertical aerial photographs has failed to decipher the geological record presented by the volcanic formations in this well-exposed section. Large parts of the Vaigat section will remain inaccessible for field sampling and

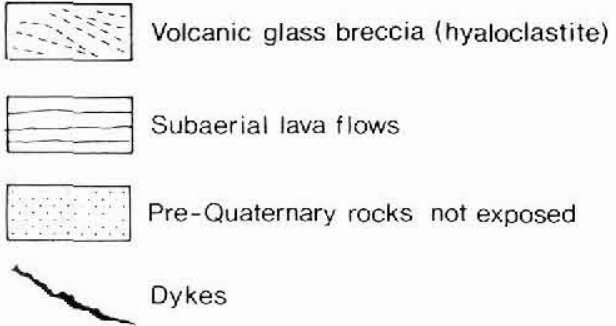

Fig. 3. A cross section through the Tertiary volcanic rocks of the Vaigat Formation at the western end of the Vaigat coastal profile at Nuusap Qaqqarsua. The profile is a vertical projection on a plane which strikes $110^{\circ}$. The profile records a situation, where volcanic productivity and basin movements caused rapid fluctuations of the position of the shoreline. Subaerial conditions are recorded by sequences of lava flows, while subaqueous conditions are recorded by foreset-bedded hyaloclastite horizons, marked I to VI. A detailed profile is given in Fig. 4, and the dips and strike variations of the foreset beds from some of the hyaloclastite horizons in Fig. 11.

close distance observations with presently known field techniques.

\section{Field work}

The photogeological analysis presented below is based on a volcanic stratigraphy (Pedersen, 1985: Larsen \& Pedersen, 1990) which is again based on both field and laboratory work carried out by L. M. Larsen and A. K. Pedersen.

The field investigations were carried out as traverses from nine camps along the section supplemented by boat-supported one-day traverses. In addition field visits and sampling of otherwise inaccessible parts of the section were carried out from a helicopter. After the photogrammetrical compilation additional field work and sampling were carried out in 1991 from one field camp, supplemented by some hours of helicopter reconnaissance. Observations and sample sites were marked on aerial photographs during the field work. In addition, the paper copies of the hand-held photographs, already used to mark control points were also used to mark field observations and sample positions, which could subsequently be measured by photogrammetry with high precision after the ficld season. 


\section{Cross sections}

The compilation of long vertical cross sections represents one of the most useful applications of multi-model photogrammetry. The geological features traced in the photogrammetric instrument are digitised as strings with three coordinates that are stored in data files and at the same time projected onto a vertical plane and plotted on an on-line flat bed plotting table. The original compilation scale of the on-line manuscript plot is 1:5000. Field notes are used together with monoscopic viewing of close up field colour slides to support the interpretation of features seen on the orientated templates. The on-line plot is supplemented with hand written notes, and lithological units are hand coloured. Heights, dips, strikes, and sample locations are also measured photogrammetrically and plotted on an overlay sheet.

Fig. 3 shows a typical cross section through Nuusap Qaqqarsua at the western end of the Vaigat coastal section. It contains a series of alternating horizons of subaerial lava and hyaloclastite and gives a record of rapidly fluctuating shorelines as volcanic products poured over a sinking basin. In this particular section, the field observations and the laboratory work on the rock samples have provided a detailed volcanic lithostratigraphy, whereas the multi-model photogrammetry has provided the structure of the sequence. The geological data files obtained from several templates are combined and replotted together in smaller scales. The scale 1:20 000 was chosen for the final publication of the Vaigat section.

\section{Detailed sections}

One particularly interesting detail in the section of Fig. 3, which was noted already in the field, is a very distinctive light brown hyaloclastite horizon seen within a dark brown hyaloclastite. In order to demonstrate the zoom ability of multi-model photogrammetry, this brown horizon was analysed in greater detail. The same photographs as used for the section shown in Fig. 3 were used; detailed information was digitised and stored in separate data files, and plotted at a larger scale $(c$. 1:2000) as shown in Fig. 4. At the larger scale it became apparent that the light brown horizon extends from the

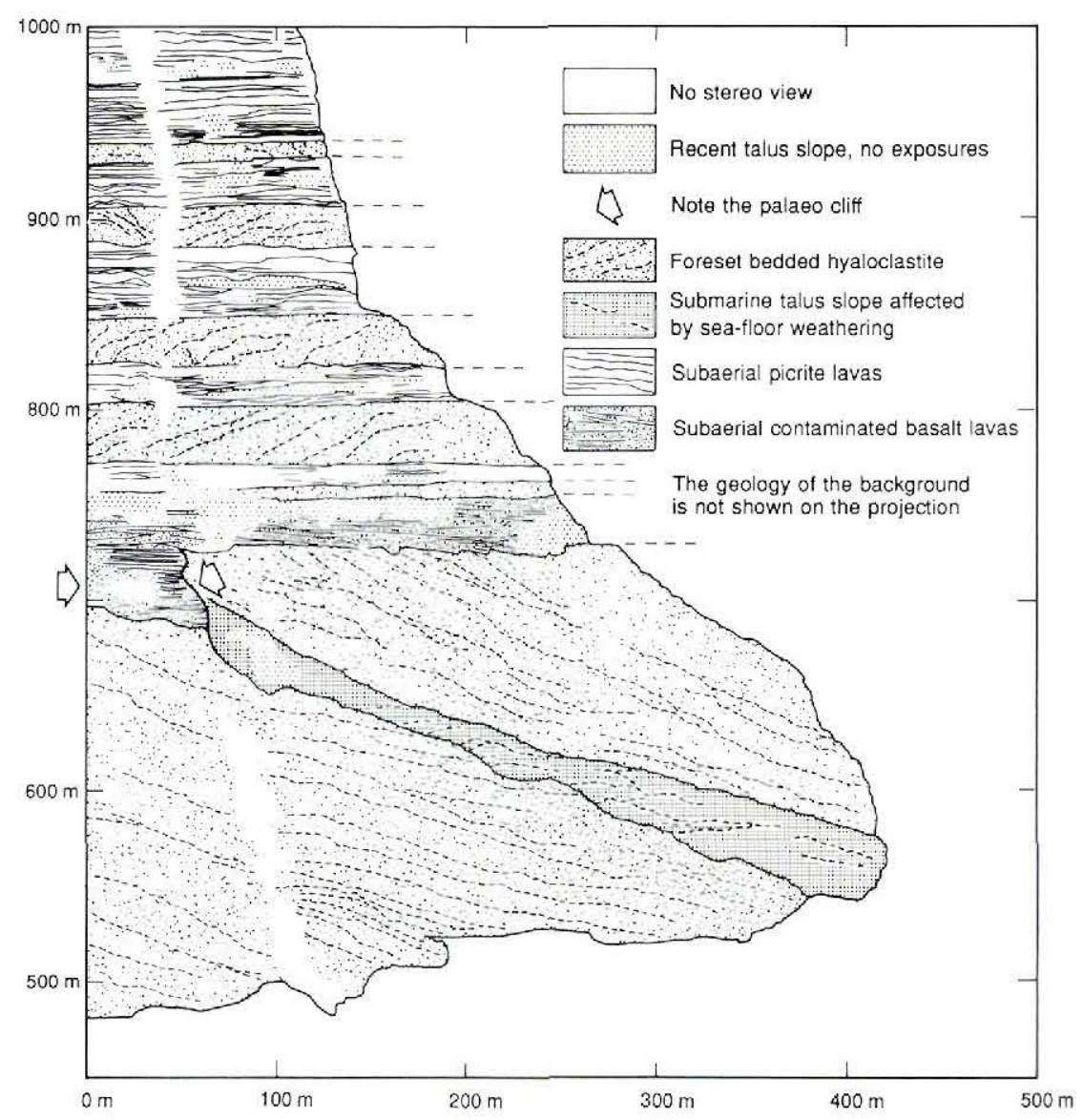

Fig. 4. Detailed profile which has been compiled from the same multi-model block as used to compile Fig. 3 at Nuusap Qaqqarsua. The profile shows how a series of contaminated lavas form a palaco-cliff (see arrows). from which extends a marine talus slope resting on foreset-bedded hyaloclastites. A series of younger lava flows subsequently overflowed the cliff and filled the ba$\sin$ with new hyaloclastites. The five separate overlying hyaloclastite horizons record short-lived transgressions and infilling of the shallow sea by hyaloclastite. The white subvertical zone seen in the left side of the figure are areas, where there is no stereoview due to the topography. 
sea-bottom at a palaeodepth of at least $200 \mathrm{~m}$ and upwards along a former shelf-slope ending at an almost vertical palaeocliff, about $40 \mathrm{~m}$ high. The light horizon is a talus slope formed during a period of volcanic quiescence by erosion of the cliff and prolonged seafloor weathering of the exposed rocks. The horizon is thus a potential site for the localisation of datable marine fossils.

This important palaeocliff was not observed in the field, because the geologist's angle of view on the ground resulted in a distorted perspective, and the identity of the light brown horizon as a talus slope was therefore not understood, when it was visited.

\section{Sections}

Vertical sections are routinely analysed with multimodel photogrammetry. Field measured and sampled sections are readily updated through photogrammetric measurements which are much more accurate than the field determinations of heights, based on altimeters. For instance, as an example, the less than $1 \mathrm{~m}$ thick horizons of red bole formed by weathering of subaerial basaltic lava flows in the warm climate of the early Tertiary can be measured with high precision in profiles from photographs at a scale of 1:20 000. Very accurate sections can be measured of completely inaccessible mountain sides. Fig. 5 gives an example of a vertical profile which contains abundant picritic pahoehoe lava flows from the Vaigat Formation. In addition a section is shown through plateau basalts from the Maligât Formation in eastern Disko which display a different volcanic lithology characterised by much thicker lava flows.

\section{Block diagram}

Block diagrams are easily constructed through multimodel photogrammetry. First a surface contour map is compiled and stored in order to visualise the topography of the landscape to be plotted in perspective. Geological boundaries and features like bedding are measured or extracted from earlier measurements. All data are then plotted in perspective as seen from a

Fig. 5. Vertical section through Tertiary volcanic rocks from Nuussuaq and Disko, compiled from multi-model photogrammetry. Section 1 is from the upper part of the volcanic sequence from the Vaigat Formation at Nuusap Qaqqarsua and contains many thin picritic pahoehoe lava flows. Section 2 is from Frederik Langes Dal in eastern Disko and presents a part of the Maligât Formation with very voluminous basaltic aa lava flows.
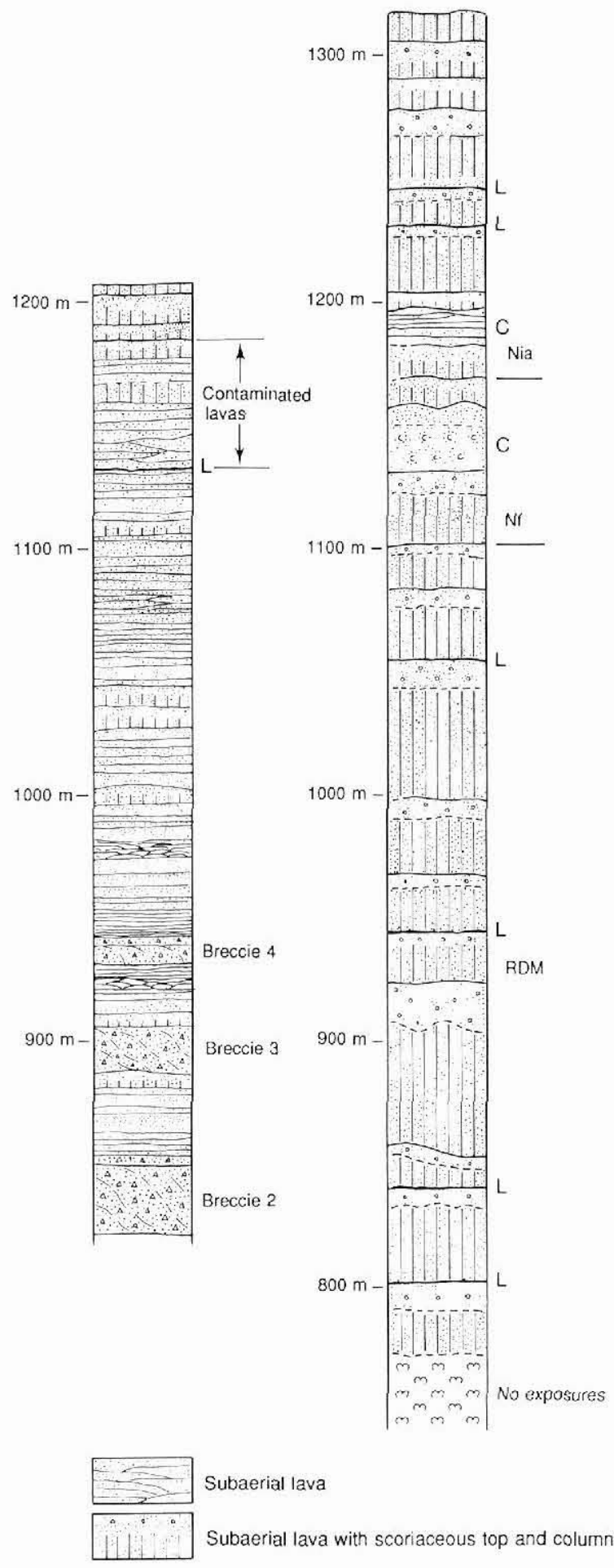

Subaerial lava

Subaerial lava with scoriaceous top and columnar jointing

C Sediment contaminated volcanic rocks

Lava flow in transition to subaqueous facies

Foreset-bedded hyaloclastite

L Laterite 

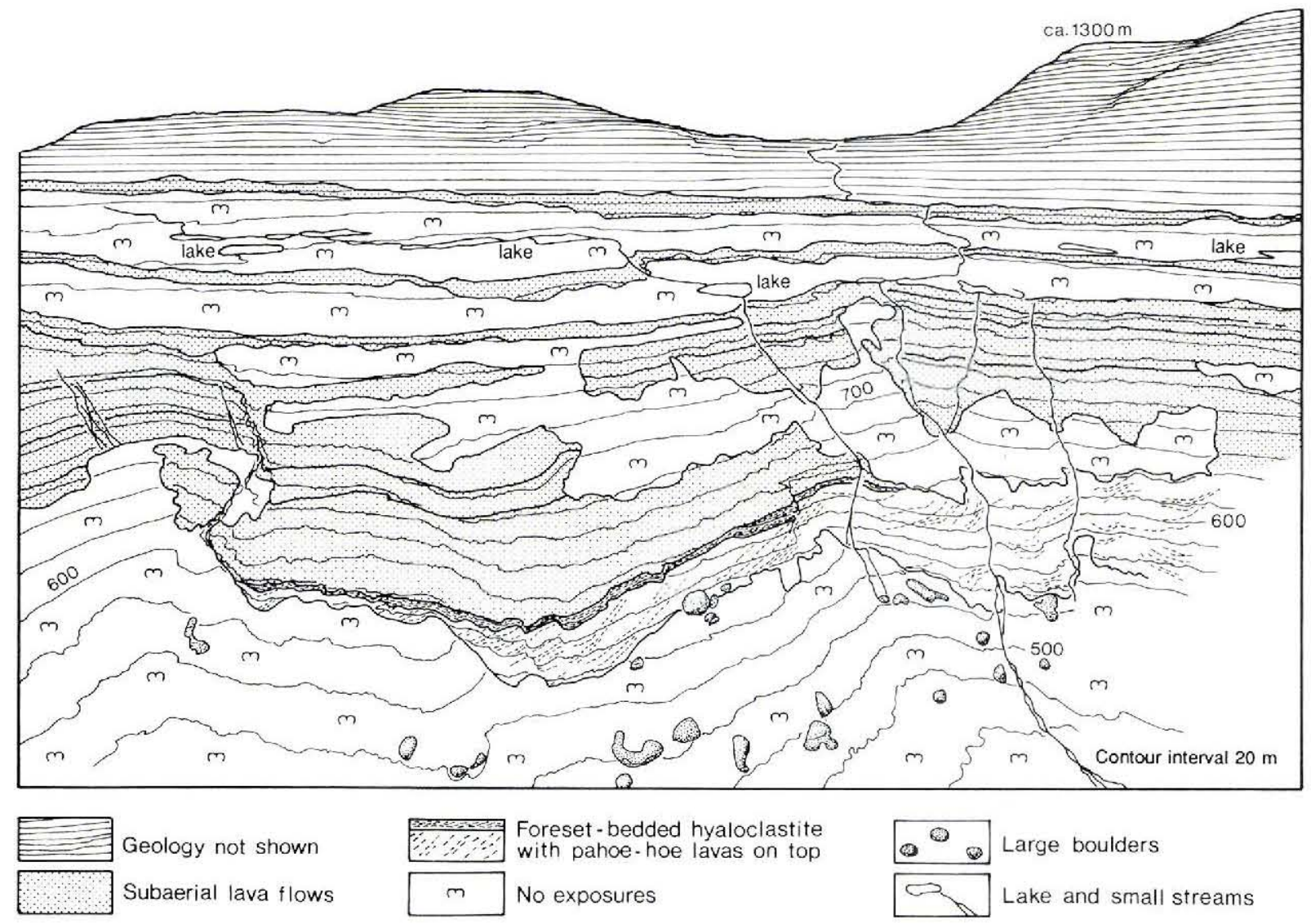

Fig. 6. Block diagram showing the innermost part of Kvandalen on Disko. The data used for the construction was obtained in several steps. First, a topographic map with $20 \mathrm{~m}$ contour intervals was obtained by combining measurements in a multi-model block for the foreground with measurements in an oblique aerial photopair for the background. Then a geological compilation was made in the multi-model block. The data were plotted in an oblique projection as seen from a distance of $500 \mathrm{~m}$ and from $30^{\circ}$ above the horizon. The geology shown is the lower part of the Maligât Formation. In the foreground the foreset-bedded hyaloclastites from the pahoehoe series (Larsen \& Pedersen, 1990) are overlain by a series of voluminous plateau basalt lavas.

chosen angle above the horizon, in a given direction, and from a given distance. In Fig. 6, the lowermost part of the Mâligat Formation in Kvandalen on Disko is presented. The diagram displays the transition from foreset-bedded hyaloclastites to lava flows erupted over a land surface which became less water-soaked with time.

The geological features of a steep wall seen in the foreground of the block diagram is mapped in extreme detail (Fig. 7) and gives an example of the span of the zoom capability of the multi-model method. The section was measured from the same stereomodels (photographs at scale $c$. 1:15 000) as used in Fig. 6. By plotting the section in scale 1:1000 and by recording the columnar jointing of the individual lava flows it is seen how the cooling pattern changed in time in response to changing environment. One of the stereo pairs used for the compilation of Figs 6 and 7 is shown as Fig. 8.

\section{Basin movements}

During the multi-model compilations it became possible to document basin movements and to constrain them in space and time. The method has great potential in recording and analysing low angle unconformities in plateau basalt terrains which is very difficult to do during geological field work. The basin movements are analysed by measuring geological boundaries like volcanic facies transitions from subaerial to subaqueous environments, and by recording the geological boundaries of individual volcanic units such as lava flows. Important information is gained by mapping out features such as tops or bottoms of such units, and second order features like thicknesses or dips and strikes.

Fig. 9 demonstrates the geometry of filling of a prominent marker horizon of contaminated volcanic rock into a marine basin. The filling event was well under- 
Fig. 7. A detailed vertical section compiled from the same multi-model block as used for the block diagram in Fig. 6. The profile shows four lavas from the Maligât Formation. The columnar jointing patterns have been measured (thin lines) and show a substantial coarsening upwards from flow to flow, indicating that the lavas cooled in successively less humid environments.
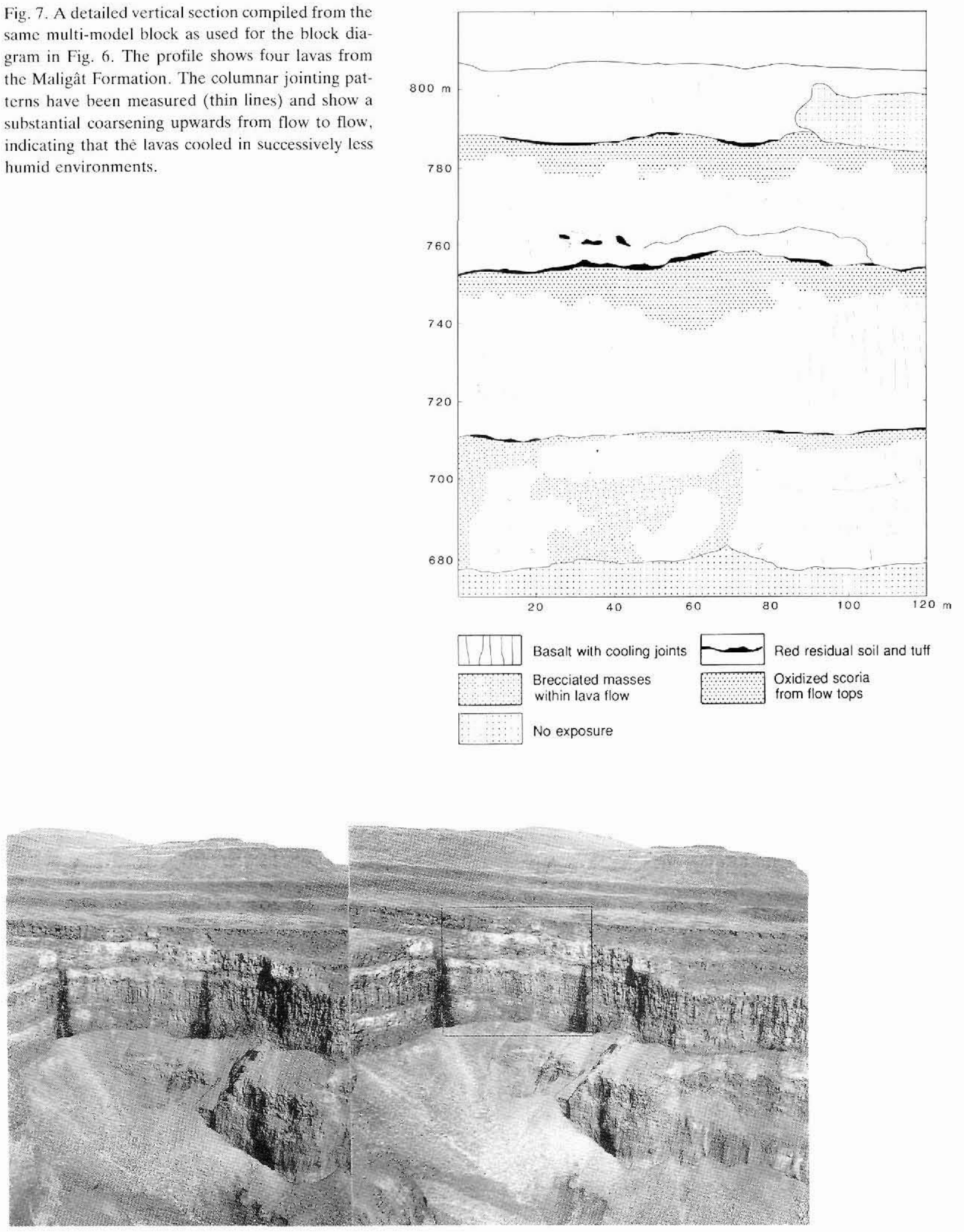

Fig. 8. Stereopair showing the corrie in the innermost part of Kvandalen which is compiled as part of a block diagram in Fig. 6. The frame indicates the position of the section in Fig. 7. 


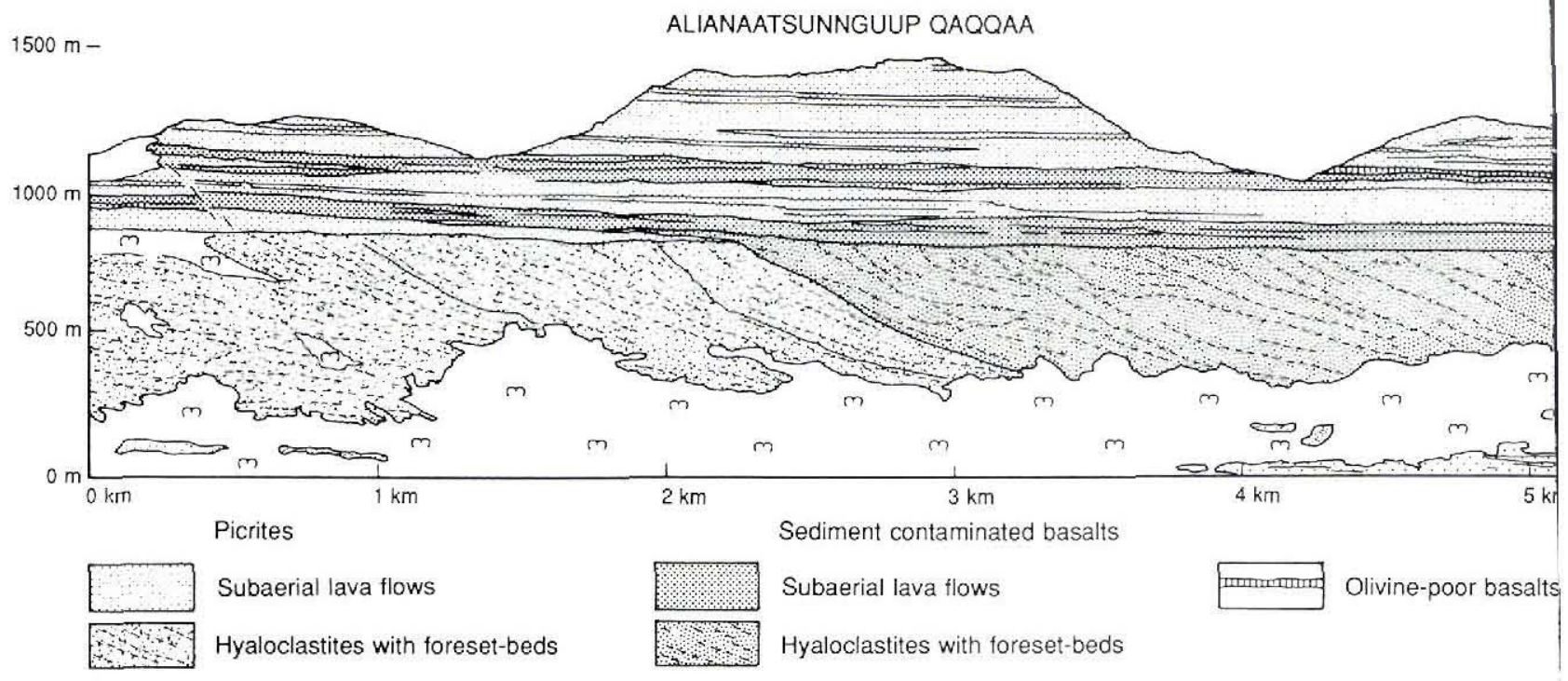

stood and sampled in the field. The multi-model compilation demonstrates how a fairly thin lava series has flowed subaerially for many kilometres until the flows encountered the old shore line and continued down- slope transformed into hyaloclastite to approach the old sea bottom at a water depth of about $450 \mathrm{~m}$. The basinfilling continued as successive lavas entered the sea, and when the last contaminated flow entered the water, the

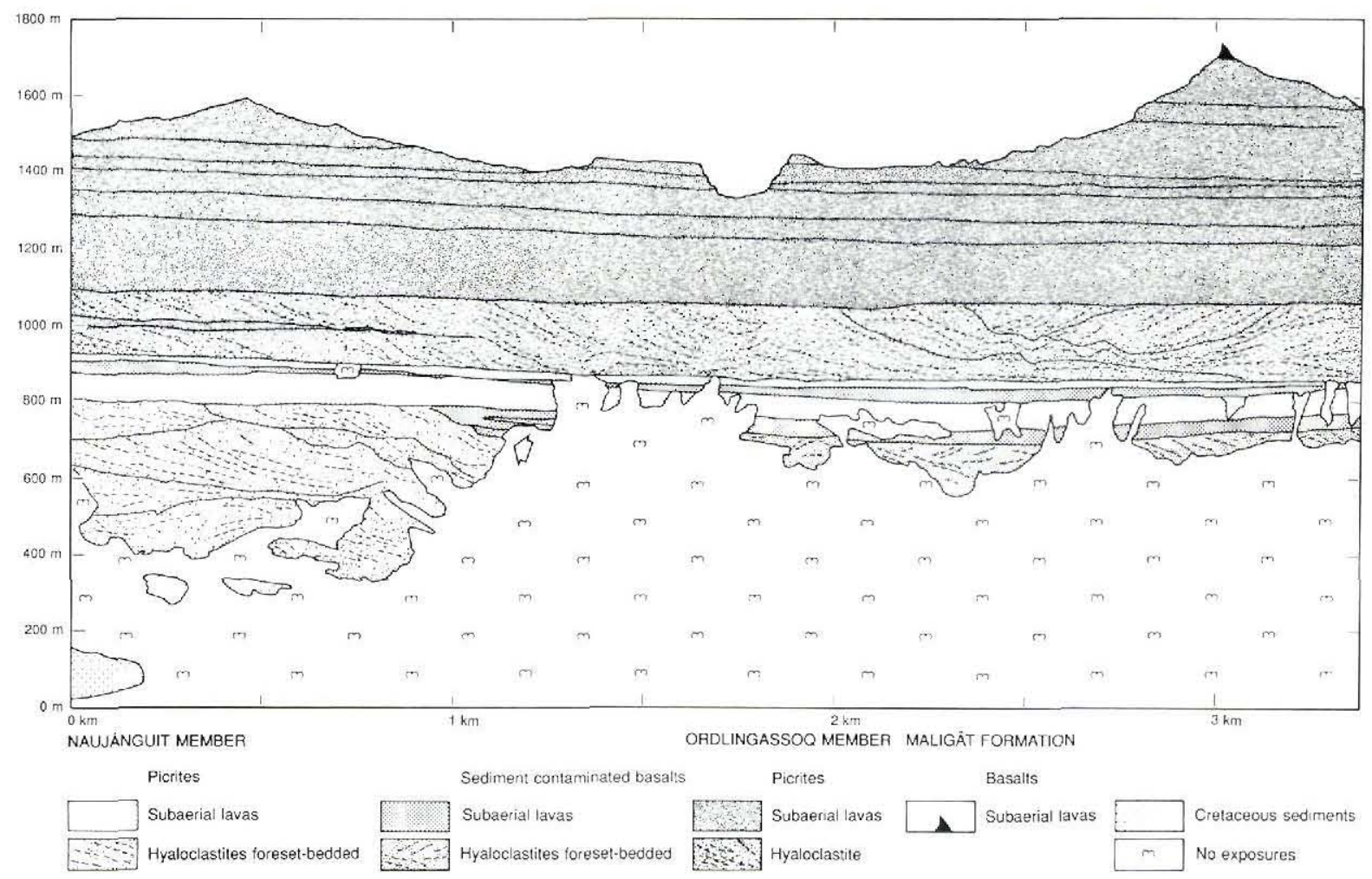

Fig. 10. Above: a vertical profile through the Tertiary volcanic rocks of the Vaigat Formation at Nuuk Qiterleq. The strike of the profile is $110^{\circ}$. In this profile. the lower part of the Vaigat Formation was affected by syn-volcanic basin movements, indicated by the wavy form of the lava-to-hyaloclastite transition and by the marked unconformity (see arrow) where subaerial lavas are 


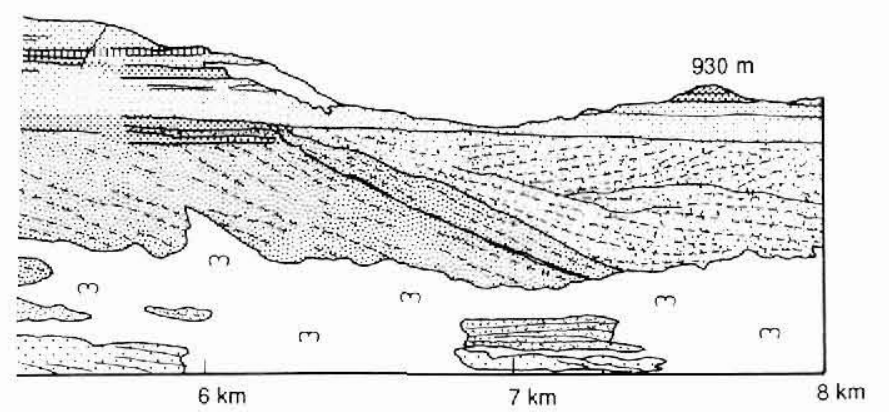

Cretaceous sediments

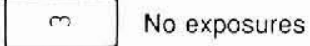

Fig. 9. A vertical cross section through the Tertiary volcanic rocks of the Vaigat Formation at Alianaatsunnguup Qaqqaa. The strike of the profile is $110^{\circ}$. The profile illustrates how a sequence of sediment contaminated lava flows enters a marine basin to form foreset-bedded hyaloclastites. The marine basin was about 400 to $600 \mathrm{~m}$ deep at the time of filling, and while the hyaloclastites prograded about $3.5 \mathrm{~km}$ into the sea the equivalent lava sequence is only 70 to $90 \mathrm{~m}$ thick. shore in this section had progressed about 3.5 kilometres seawards while the subaerial sequence of lavas is only 70 to $90 \mathrm{~m}$ thick.

Fig. 10 shows a feature picked up by multi-model photogrammetry and not seen in the field because of distorted perspective. The figure shows a marker horizon of subaerial contaminated lavas piled up against hills of submarine hyaloclastites, which must have been

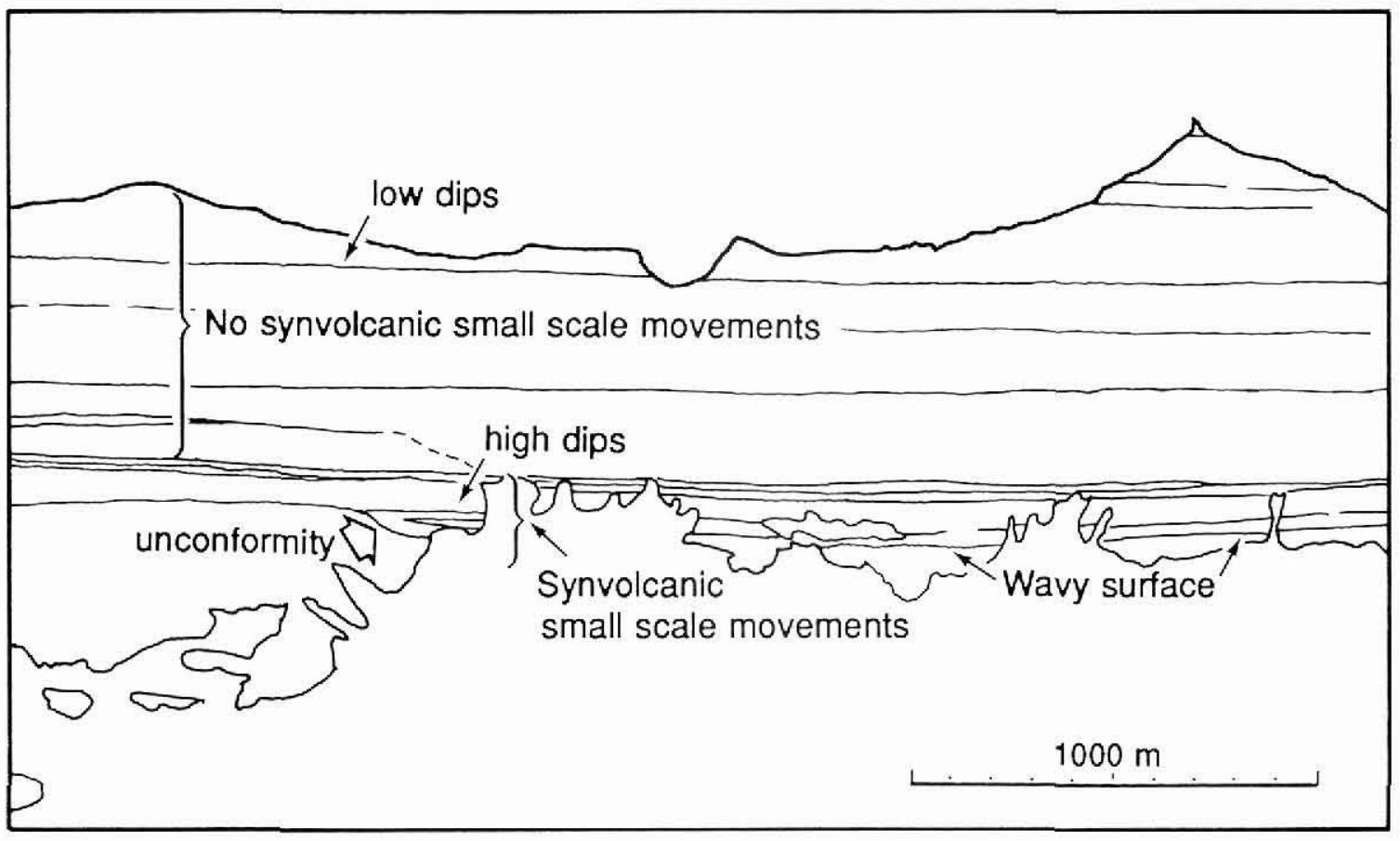

banked up against foreset-bedded hyaloclastites. The younger part of the Vaigat Formation from the base of the upper hyaloclastite to the top of the formation was not affected by these local movements. Above (right): an overview of the profile showing the areas of critical importance for the structural interpretation. 

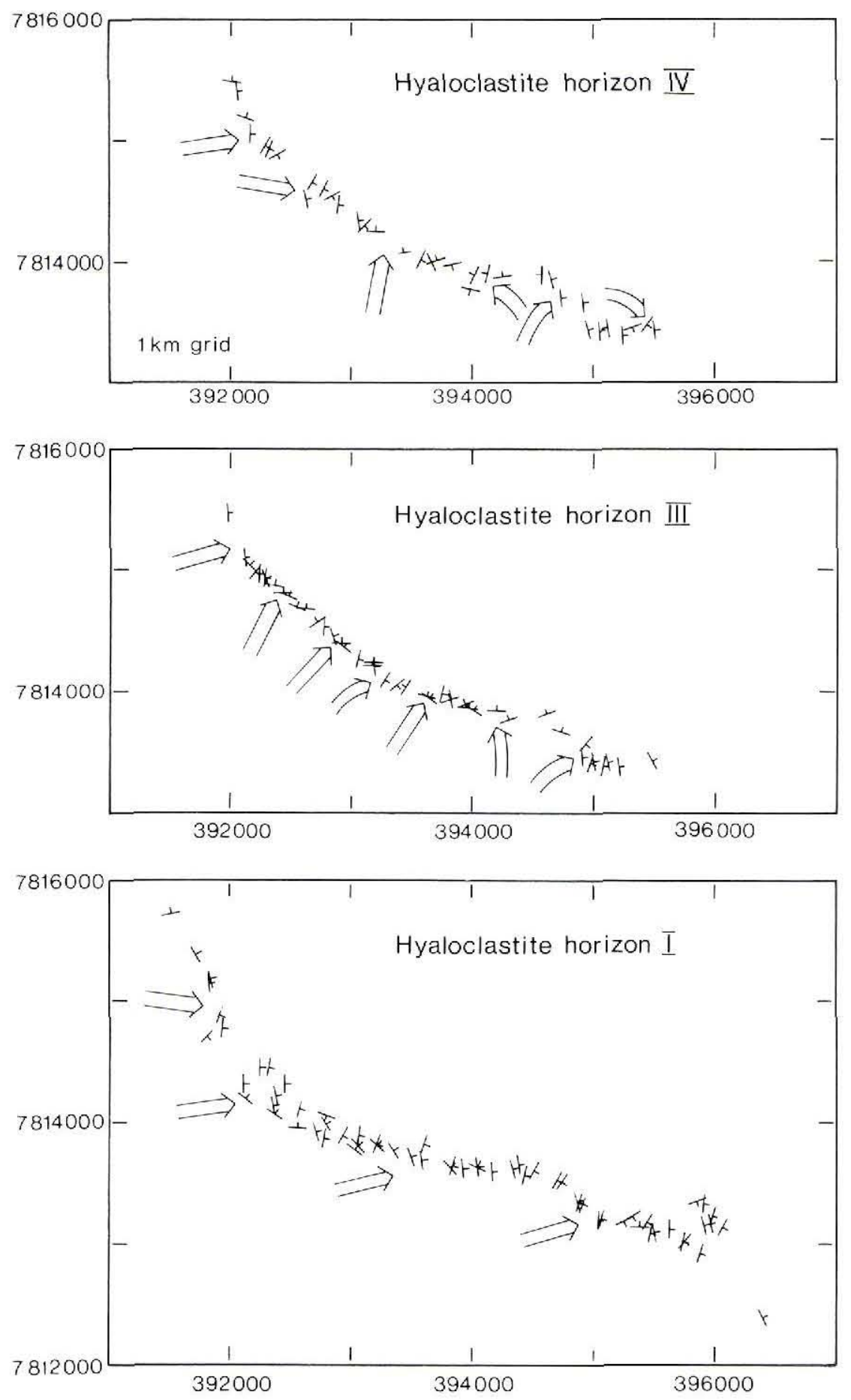

Fig. 11. Dip and strike measurements of foreset-bedded hyaloclastites shown in a horizontal projection (UTM grid coordinates in $m$ ) from Nuusap Qaqqarsua shown in Fig. 3. Arrows indicate flow directions.

Horizon I, at the base of the profile, is 300 to $400 \mathrm{~m}$ thick and was filled when basaltic lava flows entered the basin from the west. Horizon III, which is less than 50 $\mathrm{m}$ thick, was formed by picritic lava flows which entered the shallow marine basin from a general south-westerly direction.

Horizon IV, which is generally less than $30 \mathrm{~m}$ thick was also formed from picritic lavas. The very considerable variation in dips and strikes of the foresetbeds in this hyaloclastite horizon indicates that the lavas entered from several directions and formed breccia-tongues protruding into the shallow basin. uplifted above sea level by local basin movements. A transition where the contaminated lavas enter water has a wavy surface instead of the expected subhorizontal surface. Slightly higher up in the sequence another small series of contaminated lavas has been partly channelled between updoming picrite lava flows. These were expected to show less local topography. All this adds up to demonstrate local basin movements during the eruption of parts of the volcanic sequence. The volcanic rocks overlying this sequence show no evidence of local movements during the later part of the volcanism.

In combination with the analysis of basin movements 
Fig. 12. Tertiary volcanic rocks from a mountain slope between Giesecke Monument and point 1760 near the Vaigat coast on Nuussuaq. In the foreground hyaloclastites are seen from the top of the Vaigat Formation (H), invasive lava flows (I) and Tertiary sediments (S). In the upper part is seen voluminous plateau basalts from the Maligât Formation. A lava flow, which consists of plagioclase porphyritic tholeiitic basalt, and which has been measured photogrammetrically (see Figs 13 and 14) is marked (Th).

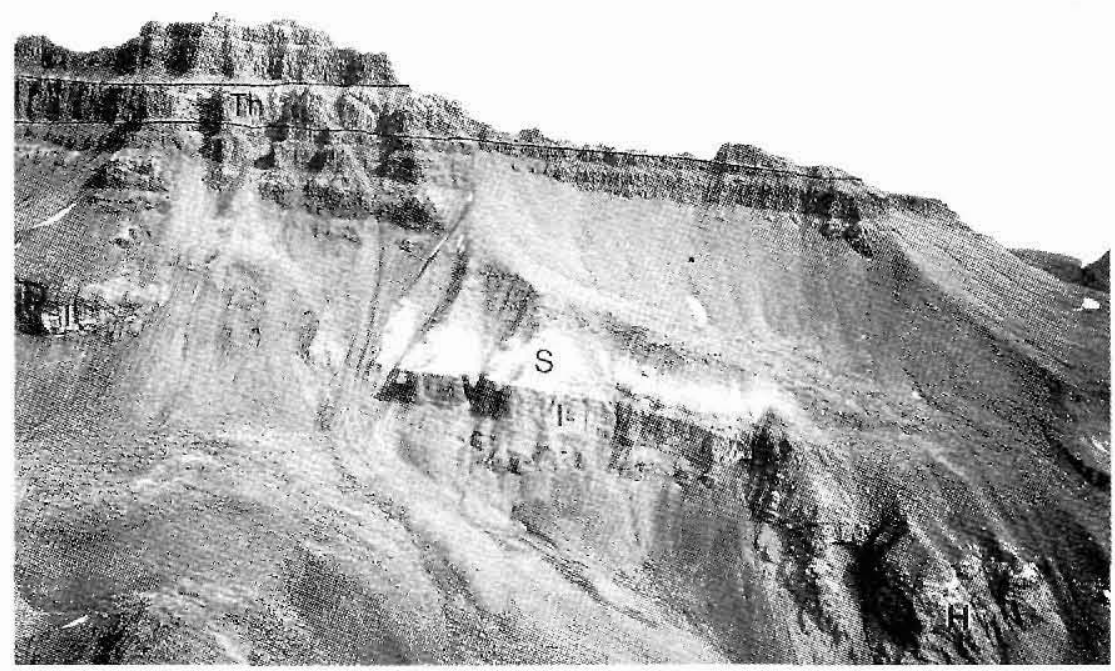

it is important to investigate how and from what directions the basins were filled by volcanic material. In the vertical section at Nuusap Qaqqarsua (Fig. 3) the flow directions of two thin horizons of marine foreset-bedded hyaloclastite found within subaerial picrite lava flows are compared with the basal hyaloclastite by ana- lysing the dips and strikes of the beds. In Fig. 11 numerous dip and strike measurements have been plotted in a horizontal projection, one for each of the three horizons. It is demonstrated that the basal hyaloclastite was formed by inflow of lavas from the west, whereas the lava flows filling the thin hyaloclastite horizons entered

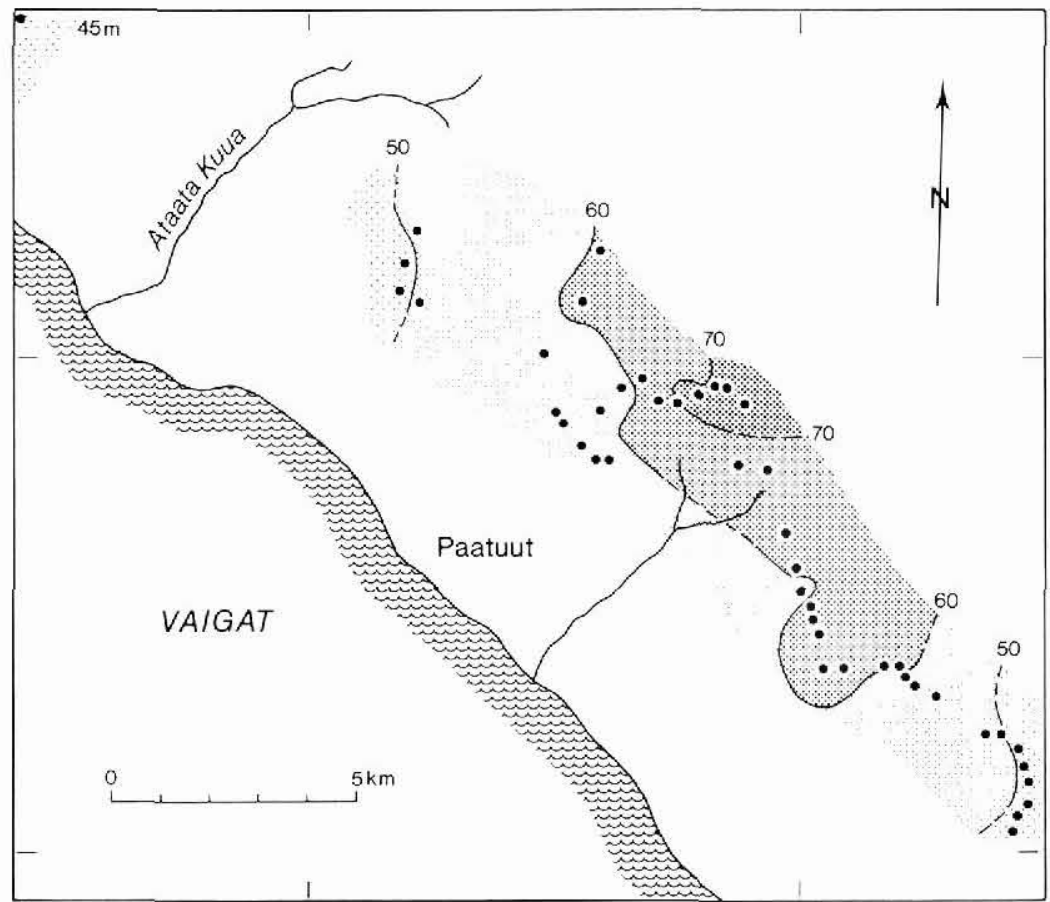

Thickness of lava flow

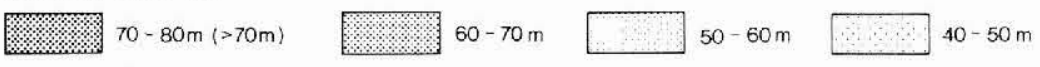

- Thickness measurement by multi-model photogrammetry
Fig. 13. Regional variation in the thickness of a single voluminous basalt lava from the Maligât Formation around the Paatuut area at the Vaigat coast on $\mathrm{Nu}$ ussuaq (Th of Figs 2 and 12). The map is contoured from the individual measurements located on the figure. The lava flow is inaccessible over most of the area but could be measured in a series of multi-model blocks. The eruption site has not been localised but is supposed to be within the area of maximum thickness of above $70 \mathrm{~m}$. The map can be extended towards the north-east when more multimodel blocks have been orientated. The Maligât Formation has been removed by erosion in the white zone towards the Vaigat. 


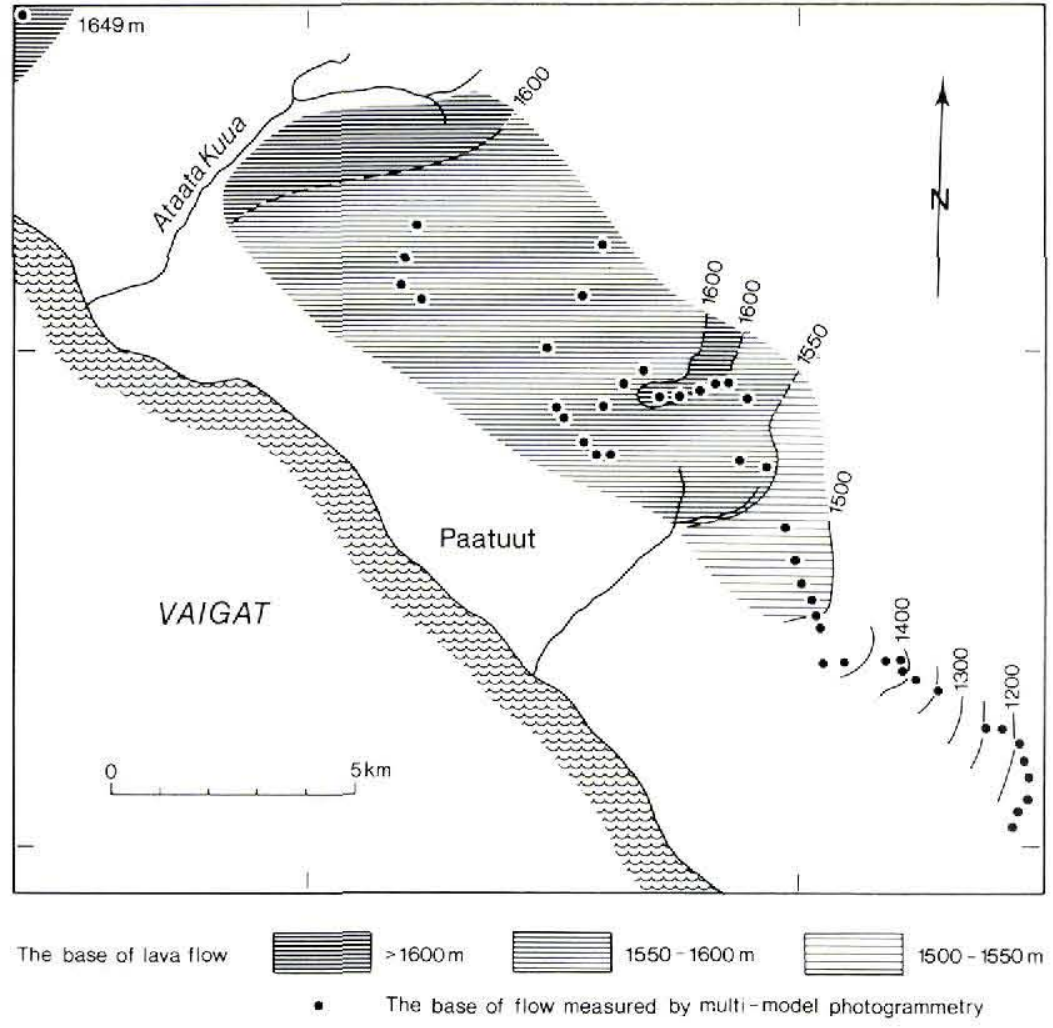

Fig. 14. Regional variation in the altitude of the base of the thick lava flow (Figs 2 and 12) shown in Fig. 13. The top of the flow is now largely horizontal in the area from Paatuut towards the north-west. The flow defines a flexure with a relative down-sagging of the eastern area by about $400 \mathrm{~m}$. The age of this post-volcanic movement is not known. the basin as a series of local tongues with somewhat varying directions, but in general coming from southerly sources. This investigation shows that multi-model photogrammetry can be applied to describe the infilling patterns of large water-filled basins at the scale of thousands of square kilometres.

In Figs 13 and 14 multi-model analysis has been used to define post- volcanic movements in the Vaigat coastal section by measuring the base and thickness of a single lava flow shown in Figs 12 and 2. In the area from Ataata Kuua to Giesecke Monument a large subaerial plateau lava from the Maligât Formation is exposed over a distance of about $25 \mathrm{~km}$. The flow varies in thickness from about $45 \mathrm{~m}$ to $78 \mathrm{~m}$ within the segment measured, and extends north and north-eastwards outside the area covered by the multi-model analysis. Such a large plateau basalt flow is supposed to record the topographical palaeorelief through ponding, restrictions in flow coverage or through lava drainage. The flow thickness map (Fig. 13), which shows a rather regular thickness variation, does not indicate an extensive relief at the time of eruption. The area, with a lava thickness of above $70 \mathrm{~m}$, is interpreted to be close to the area of outflow from the feeder system; no volcanic feeders have been observed in this area. On the other hand, the map showing the base of the flow (Fig. 14) displays a considerable variation. In the western part the base forms an almost horizontal surface, but the south-eastern part reveals a pronounced flexure bringing the base down by about $400 \mathrm{~m}$ compared to the western part. This late movement, post-dating the middle part of the Maligât Formation, demands considerable repositioning of the older volcanic and sedimentary strata when the palaeo-landscape of early Maligât Formaticn time is reconstructed.

\section{Reconnaissance}

The reconnaissance value of multi-model analysis has been tested by compiling the geology of areas where extensive geological field control already existed and areas that had only been observed from a helicopter during the photographic flight mission.

In the areas with known field control, the application of multi-model photogrammetry led to new geological discoveries and to a better control of structures.

In the areas without geological field control, an abundance of new geological information was obtained from the method. An example is about $15 \mathrm{~km}$ of the Vaigat cross section between Ataata Kuua and point 1760, which were compiled from colour photographs alone. From this area a small cross section near Paatuut is 
shown on Fig. 15. Several small subaqueous eruption sites of picrites have been found in a palaeo-lake. They were later covered by hyaloclastites when lava-flows poured into the water and filled the lake. In addition considerable local basin movements have been recorded.

This site was visited in 1991. The eruption sites discovered by photogrammetrical analysis were confirmed and several more were discovered in a zone not covered by the stereo view. In addition, important but poorly exposed mudstone sediments were found interlayered with the hyaloclastite. As a consequence, this interesting area was re-photographed to give colour stereo coverage at a larger scale.

\section{Conclusions}

In conclusion, the multi-model photogrammetric analysis of $80 \mathrm{~km}$ along the steep south coast of Nuussuaq, which combines 125 stereo models of small-frame colour photographs with 6 vertical and 5 oblique aerial photograph models has demonstrated that:

- the method allows geological analysis and compilation in a very steep-walled, alpine terrain;
- where required, the analysis can be carried out with high precision and in extremely great detail;

- multi-model work reveals an abundance of important geological features which may not be recognised during normal field work or on black and white aerial photographs.

The multi-model analysis is very useful for geological reconnaissance, provided that the general geology is known. It enables surprisingly detailed compilations to be made in areas that have been passed just once during the flight of a helicopter or an aeroplane. It is therefore of considerable value for the planning of detailed field work and sampling.

Compilation of geology by the multi-model approach has the advantage that repeated and rapid comparison of the lateral variation of geological units facilitates correlation and leads to the most favourable selection of geological marker horizons.

The ability to reset many templates rapidly is valuable during the analysis of individual units over large distances, and it is important during the analyses of second order features like thicknesses, and dips and strikes of selected units.
Fig. 15. A vertical profile through Tertiary volcanic rocks north of Paatuut Puiattua. The strike of the profile is $135^{\circ}$. The profile shows the uppermost part of the Vaigat Formation and the lower part of the Maligât Formation. The compilation was made before the area was visited in the field. The profile demonstrates considerable syn-voleanic basin movements and a series of picritic subaqueous eruption sites in the Vaigat Formation.

Note at 1: Strong syn-volcanic down-sagging of subaerial lava flows.

Note at 2: Traces of mudstones, which were found when the area was later visited in the field. Filled asterisks mark picritic eruption sites.

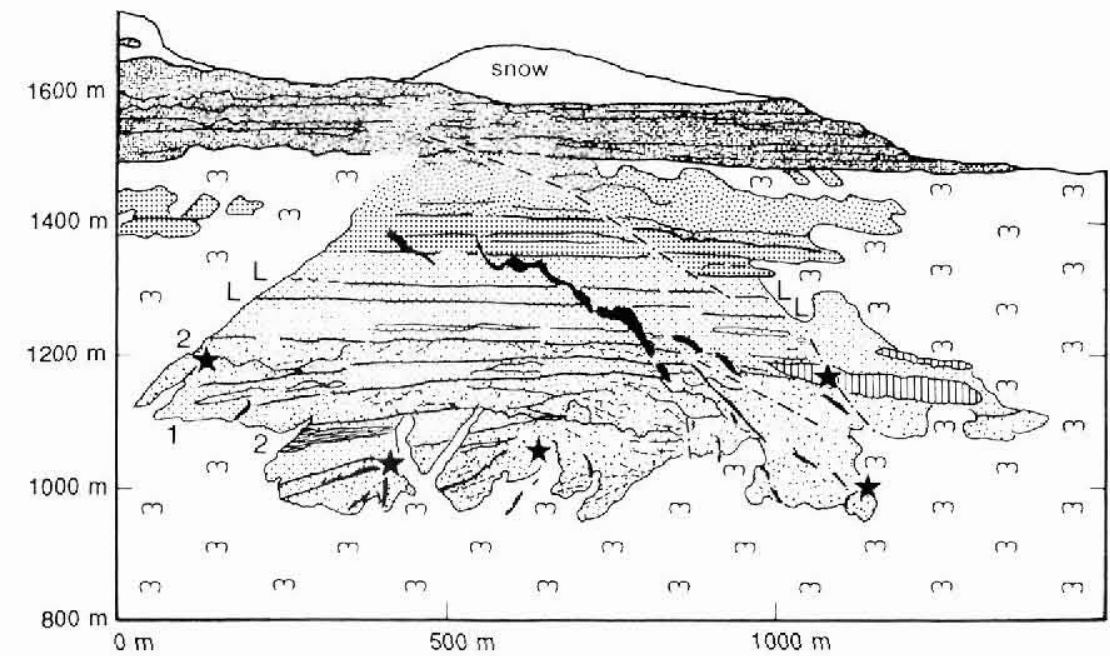

\section{VAIGAT FORMATION}

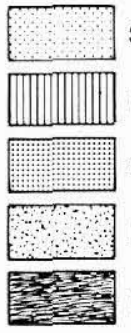

L Laterite horizon

Mudstone

\section{MALIGÂT FORMATION}

Subaerial picrite lava flow

Picrite body with columnar jointing

Feldspar-phyric evolved basalt lava flows

Picritic hyaloclastite with foreset-beds
Lava flow, transition between subaerial and subaqueous facies

Subaerial basalt lava flow

Eruption site

Dyke intrusion

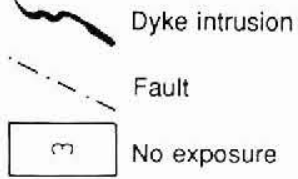


The analyses show that multi-model photogrammetry may profitably be used in combination with vertical and oblique aerial photographs. Despite the distinctly poorer geological resolution of the latter, the combined analysis using different scales and directions of views, gives the best overall interpretation.

Multi-model photogrammetry has proved to be a very powerful new tool in the geological analysis of volcanic and sedimentary basins along the well exposed continental margins of Greenland.

Acknowledgements. Field support for this project from GGU, the Danish Natural Science Research Council (grant no 118949-1), and the Arctic Station in Godhavn is gratefully acknowledged. F. Ulff-Møller took some of the colour photographs used in the analysis. R. Larsen is thanked for drafting many illustrations. Critical comments from A. A. Garde and L. M. Larsen belped to improve this contribution.

\section{References}

Dueholm, K. S. 1992: Geologic photogrammetry using standard small-frame cameras. Rapp. Grønlands geol. Unders. 156 (this volume).

Dueholm, K. S. \& Pedersen, A. K. 1988: Geological pho- togrammetry using oblique aerial photographs. Rapp. Grønlands geol. Unders. 140, 33-38.

Dueholm, K. S. \& Pedersen, A. K. 1990: Multi-model photogrammetry applied to arctic terrains using colour slides from Greenland. Proceedings of the 3rd International Conference on Development and Commercial Utilization of Technologies in Polar Regions, Copenhagen, Denmark, 14-16 August 1990, 151-160.

Koch, B. E. 1959: Contribution to the stratigraphy of the non-marine Tertiary deposits on the south coast of the Nûssuaq peninsula, northwest Greenland with remarks on the fossil flora. Bull. Grønlands geol. Unders. 22 (also Meddr Grønland 162,1) $100 \mathrm{pp}$.

Koch, B. E. \& Pedersen, K. R. 1960: Geological map of Atanikerdluk and environs, 1:10 000. Bull. Grønlands geol. Unders. 23 (also Meddr Grønland 162,4) 38 pp.

Larsen, L. M. \& Pedersen, A. K. 1990: Volcanic marker horizons in the Maligât Formation on Disko and Nûgssuaq, and implications for the development of the southern part of the West Greenland basin in the early Tertiary. Rapp. Grønlands geol. Unders. 148, 65-73.

Pedersen, A. K. 1985: Lithostratigraphy of the Tertiary Vaigat Formation on Disko, central West Greenland. Rapp. Grønlands geol. Unders. 124, $30 \mathrm{pp}$.

Steenstrup, K. J. V. 1900: Beretning om en Undersøgelsesrejse til Øen Disko i Sommeren 1898. Meddr Grønland 24, 249-306. 